Foss. Rec., 22, 111-118, 2019

https://doi.org/10.5194/fr-22-111-2019

\title{
The second fossil species of Cathartosilvanus (Coleoptera: Cucujoidea: Silvanidae) from Eocene Baltic amber
}

\author{
Vitalii I. Alekseev ${ }^{1,2}$, Andris Bukejs ${ }^{3}$, and Ryan C. McKellar ${ }^{4,5,6}$ \\ ${ }^{1}$ Shirshov Institute of Oceanology, Russian Academy of Sciences, Nahimovskiy prospekt 36, Moscow, 117997, Russia \\ ${ }^{2}$ Kaliningrad Regional Amber Museum, Marshal Vasilevskii Square 1, Kaliningrad, 236016, Russia \\ ${ }^{3}$ Institute of Life Sciences and Technologies, Daugavpils University, Vienības 13, Daugavpils, 5401, Latvia \\ ${ }^{4}$ Royal Saskatchewan Museum, 2445 Albert St., Regina, SK, S4P 4W7, Canada \\ ${ }^{5}$ Biology Department, University of Regina, Regina, SK, S4S 0A2, Canada \\ ${ }^{6}$ Department of Ecology \& Evolutionary Biology, University of Kansas, Lawrence, Kansas 66045, USA
}

Correspondence: Andris Bukejs (carabidae@inbox.lv)

Received: 3 September 2019 - Revised: 2 October 2019 - Accepted: 9 October 2019 - Published: 7 November 2019

\begin{abstract}
A new fossil species of the silvanid flat bark beetle genus Cathartosilvanus Grouvelle is described and illustrated from Baltic amber. Cathartosilvanus siteiterralevis sp. nov. differs from recent and fossil congeners in the distinct, sharp denticle found along its posterior pronotal angle. The phenomenon of specific body parts becoming disconnected, and the compression of specimens is briefly discussed and interpreted in the context of amber taphonomy. The specimen under study appears to be an uncommon case of a weakly sclerotized beetle imago becoming entrapped in resin shortly after moulting.
\end{abstract}

\section{Introduction}

Silvanid flat bark beetles have only rarely been reported as inclusions from Eocene Baltic amber. Up to now, only four species have been described, namely Airaphilus denticollis Ermisch, 1942 (probably belonging to Psammoecus Latreille, 1829), Dendrobrontes popovi Kirejtshuk, 2011, Mistran ot Alekseev \& Bukejs, 2016, and Cathartosilvanus necromanticus Alekseev, 2017. Additionally, Silvanus sp. and Nausibius sp. have been reported from the Baltic amber, and the genus Cryptamorpha Wollaston, 1854 has been mentioned from Eocene Bitterfeld amber (Hope, 1836; Berendt, 1845; Menge, 1856; Helm, 1896; Handlirsch, 1908, 1925; Klebs, 1910; Bachofen-Echt, 1949; Larsson, 1978; Spahr, 1981; Hieke and Pietrzeniuk, 1984).
The geological backgrounds of the Baltic and Bitterfeld amber deposits have recently been reviewed (Standke, 2008; Weitschat and Wichard, 2010), and the interconnectedness of these deposits has been assessed on the basis of arthropod inclusions (e.g., Hoffeins and Hoffeins, 2003; Szwedo and Sontag, 2013; Dunlop et al., 2018) and geochemistry (Wolfe et al., 2016). Amber from the former Palmnicken mine (Yatarny settlement, Kaliningrad, Russia) is part of a commercially mined deposit of Baltic amber. In the present paper, we provide a description of a new species of the genus Cathartosilvanus from this fossil resin.

\section{Material and methods}

The material examined is deposited in the palaeontology collection of the Royal Saskatchewan Museum (Regina, Saskatchewan, Canada) (RSM).

Observations of this specimen were made using a Nikon SMZ745T stereomicroscope. Photographs were taken using a Visionary Digital imaging system, consisting of a Canon EOS 5D camera with a Canon MP-E $65 \mathrm{~mm}$ macrophotography lens, attached to an automated camera lift with studio flash lighting. Extended depth of field at high magnifications was achieved by combining multiple images from a range of focal planes using Helicon Focus 6.8.0 software, and the resulting images were edited to create figures using Adobe Photoshop CS5. 
The following sources were used for the comparison with recent genera: Halstead (1973), Thomas (1993), and Fried$\operatorname{man}(2015)$.

\section{Systematic palaeontology}

Superfamily Cucujoidea Latreille, 1802

Family Silvanidae Kirby, 1837

Subfamily Silvaninae Kirby, 1837

Genus Cathartosilvanus Grouvelle, 1912

\section{Note}

The studied amber specimen shows the combination of characters unequivocally corresponding to the subfamily Silvaninae: subparallel body shape, pentamerous tarsi with tarsomere 4 smallest; closed procoxal cavities; 11-segmented antennae with distinct antennal club; antennal scape comparatively short, about as long as wide; frons laterally without longitudinal sulcus; and frontoclypeal suture absent.

The beetle under consideration is assigned to Cathartosilvanus based on the combination of the following characters: (1) lateral sides of pronotum simple, not margined; (2) anterolateral denticle on pronotum distinct; (3) all tarsomeres simple (not lobed and not incrassate); (4) femoral lines open; (5) antennomere 8 not narrower than antennomere 7; (6) antennae with distinct, three-segmented club; (7) temple welldefined; and (8) elytral striae not carinate.

Cathartosilvanus siteiterralevis sp. nov.

Figs. 1-3

ZooBank: urn:Isid:zoobank.org:act:E1CAFC19- 2BFA4DC1-B828-BF098F2D87F8

\section{Type material}

Holotype: collection number P3300.87 [RSM]; adult, sex unknown. Single beetle included in a transparent, yellow, round amber piece (with diameter of $8 \mathrm{~mm}$ and thickness of $2.5 \mathrm{~mm}$ ); preserved without supplementary fixation. Specimen is complete, but dorsoventrally compressed (possibly postmortem compression), with almost tripartite body division between head, prothorax, and the rest of body. Syninclusions: few stellate fagacean trichomes, fragments of unknown insect, and two small detritus particles.

\section{Type strata}

Baltic amber from Eocene amber-bearing blue Earth layers (mostly Bartonian age is interpreted for the extinct central European resin-producing forests according to Bukejs et al., 2019).

\section{Type locality}

Yantarny settlement (formerly Palmnicken), Sambia (Samland) Peninsula, Kaliningrad region, Russia.

\section{Etymology}

The specific epithet is derived from sit ei terra levis, an ancient Latin inscription on tombstones meaning "may the Earth rest lightly on you". The name is used as a noun in apposition.

\section{Diagnosis}

The new species from Baltic amber has the anterior edge of the pronotum almost straight and possesses a single, distinct, sharp denticle at posterior pronotal angle. In all extant species of Cathartosilvanus, lateral portions of the pronotal anterior edge obviously slope backwards to reach anterolateral angles within one-third of the edge's width or less; posterior pronotal angles are well-defined or not, but lack a sharp denticle anteriorly. Additionally, C. siteiterralevis sp. nov. can be distinguished by its weakly undulating pronotal lateral sides (finely denticulate in extant species) and by its sparse elytral punctation.

Cathartosilvanus siteiterralevis sp. nov. differs from Baltic amber congener $C$. necromanticus Alekseev in having a distinctly smaller body size $(2.3 \mathrm{~mm}$ in contrast to $3.5 \mathrm{~mm}$ in C. necromanticus); a sharp pronotal denticle at posterior angle (lacking in C. necromanticus); and sparse, fine pronotal punctation (pronotum is deeply and densely punctate in C. necromanticus).

\section{Description}

Body length about $2.3 \mathrm{~mm}$, maximum width $0.5 \mathrm{~mm}$; head length $0.35 \mathrm{~mm}$, head width (including eyes) $0.4 \mathrm{~mm}$; pronotal length $0.55 \mathrm{~mm}$, pronotal maximum width $0.45 \mathrm{~mm}$; elytral length $1.4 \mathrm{~mm}$, elytral maximum width $0.5 \mathrm{~mm}$. Habitus elongate, nearly parallel-sided, strongly flattened dorsally and ventrally; glabrous, elytra and abdomen apparently with very fine, short, sparse semi-erect pubescence. Body and appendages unicolour rufous.

Head nearly as long as wide, impunctate; forehead almost flat, vertex slightly convex. Labrum with anterior margin widely rounded. Fronto-clypeal suture absent. Compound eyes relatively small and prominent, hemispherical, with coarse facets; eyes widely separated, with distance between eyes about $6 \times$ transverse diameter of one eye. Temple very short, length about $0.3 \times$ eye length; posterior outer angle of temple acute and pointed. Antennal grooves absent. Mandibulae bidentate apically.

Maxillary palpi short; terminal palpomere elongate, spindle-shaped, truncate, about $2 \times$ as long as penultimate palpomere. Antenna short, extending to middle of pronotum; gradually thickening toward apex; 11-segmented, with indis- 


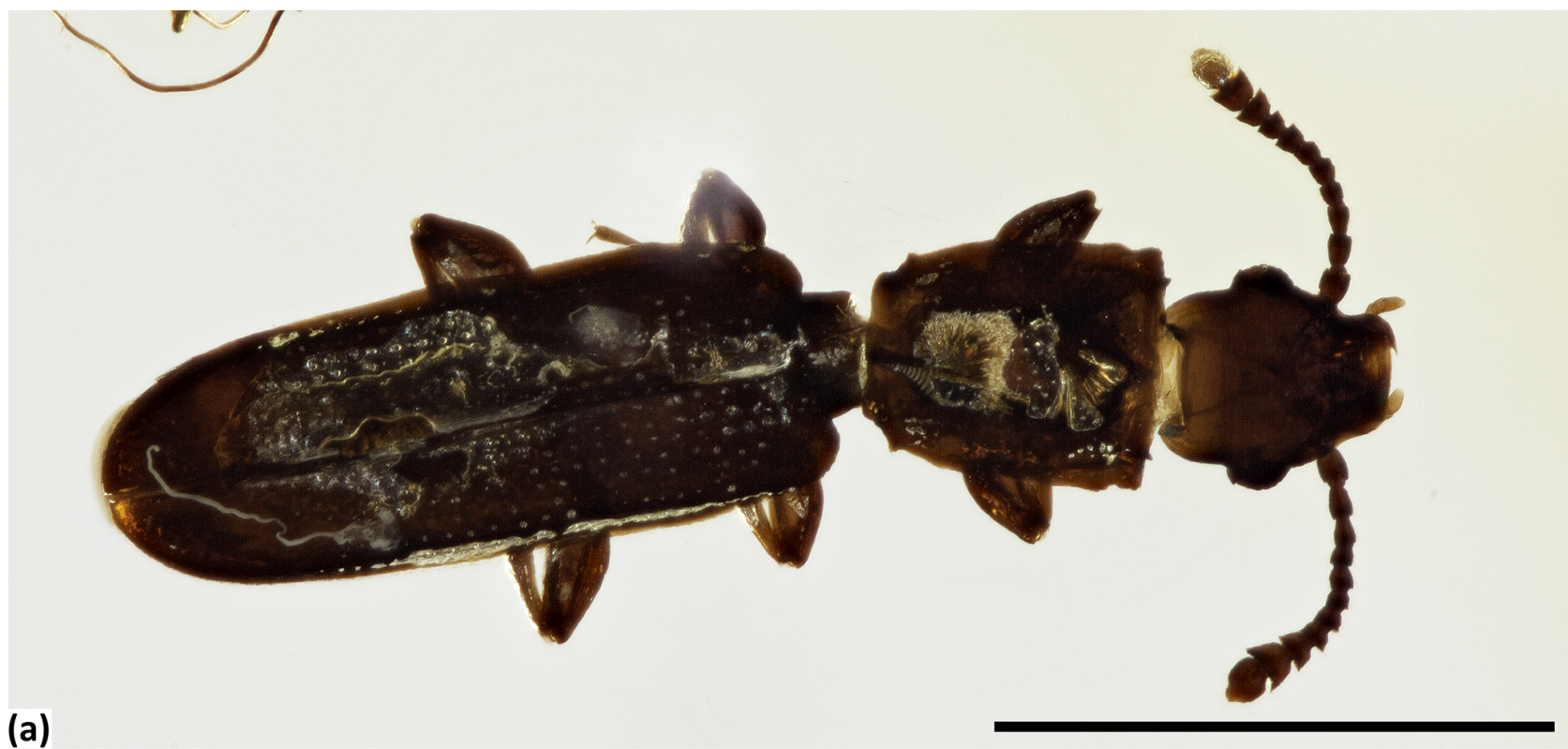

(a)

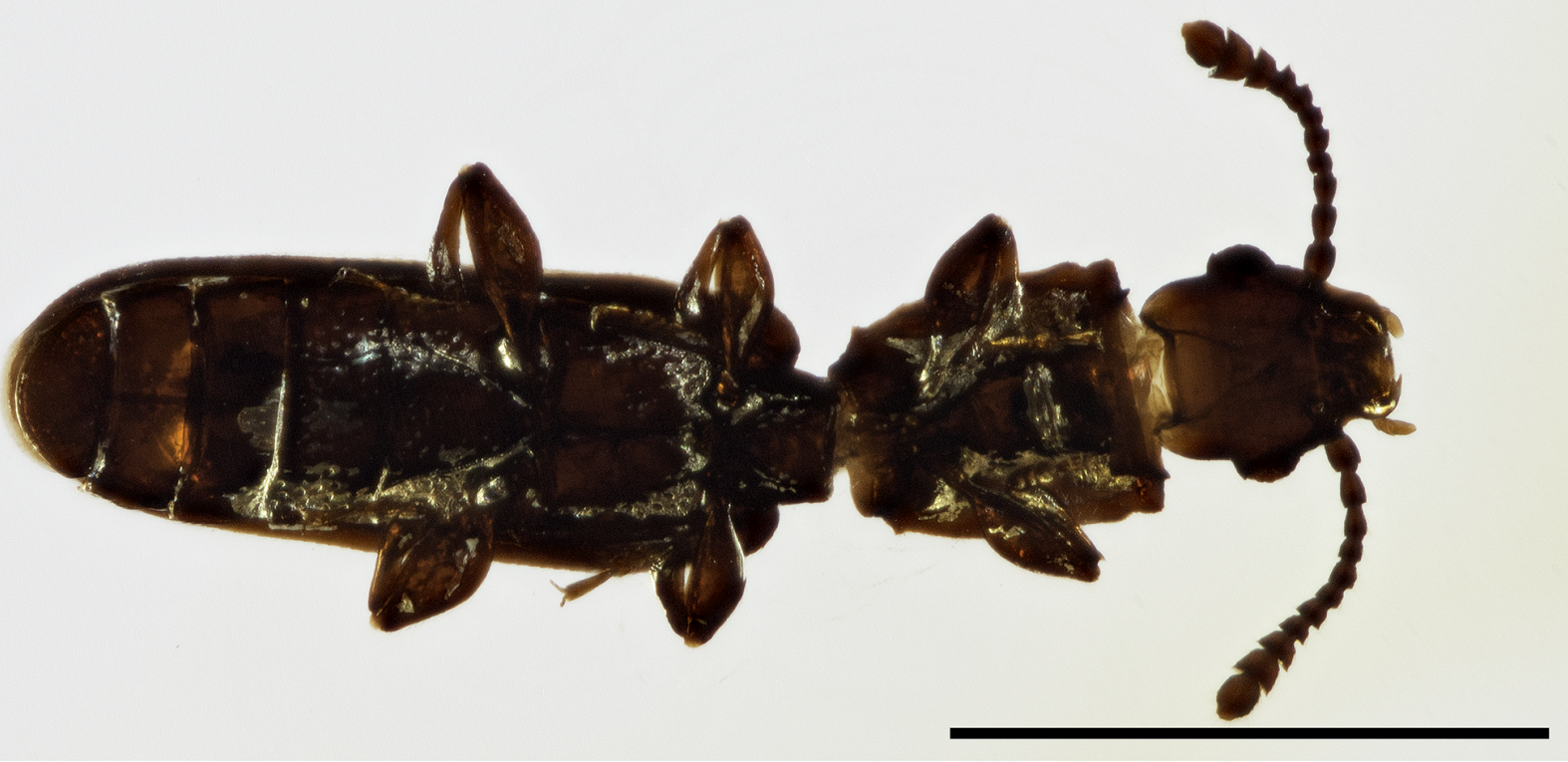

(b)

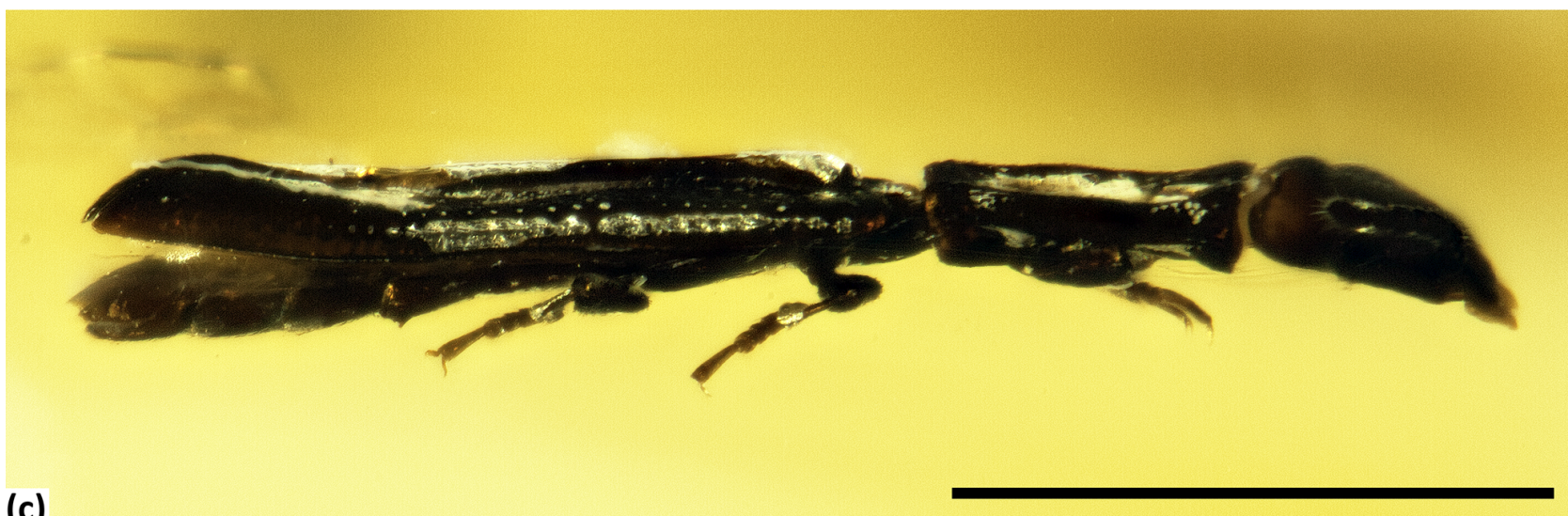

(c)

Figure 1. Cathartosilvanus siteiterralevis sp. nov., holotype, P3300.87 (RSM): (a) habitus, dorsal view; (b) habitus, ventral view; (c) habitus, lateral view. Scale bars $=1 \mathrm{~mm}$. 


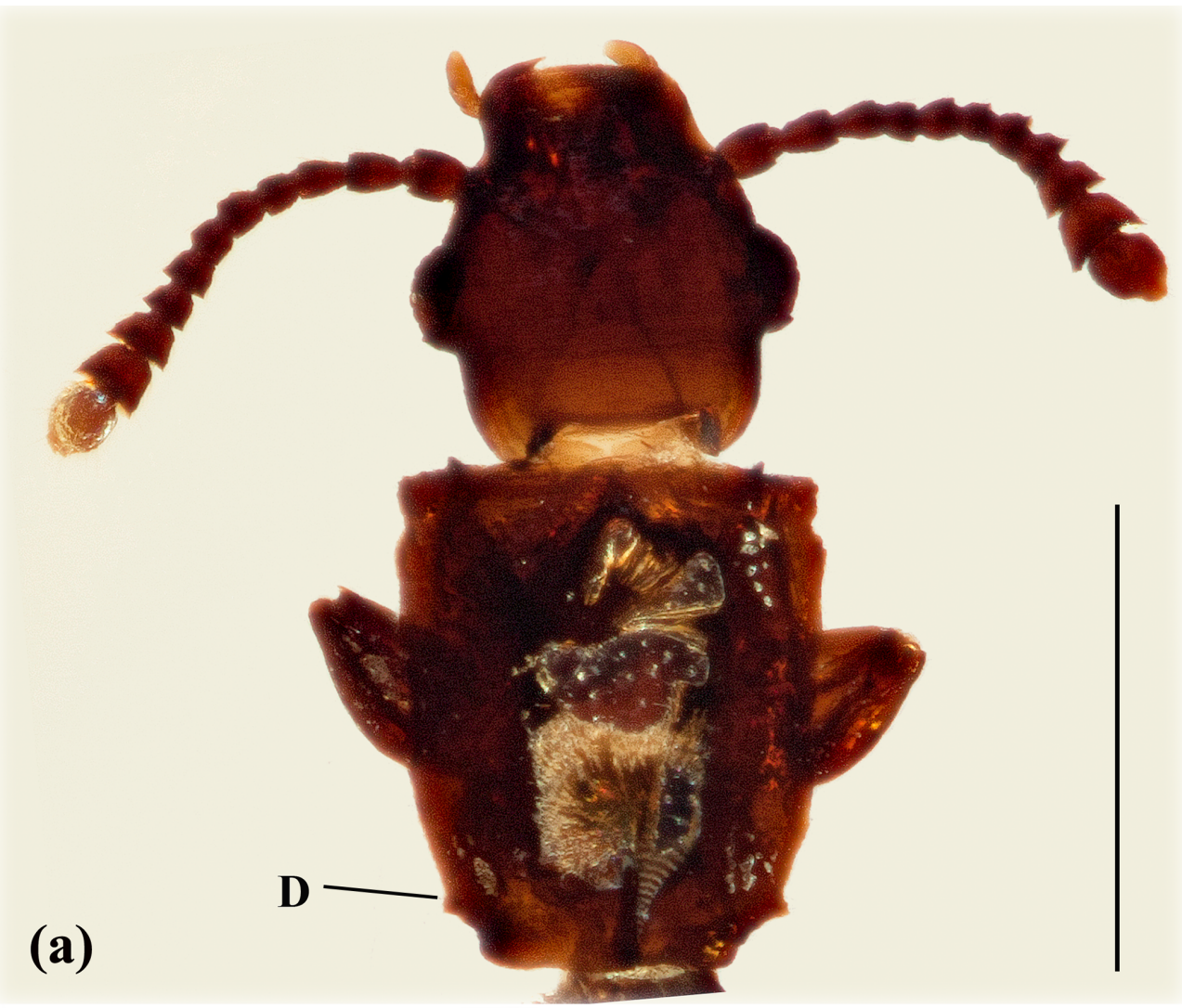

(b)
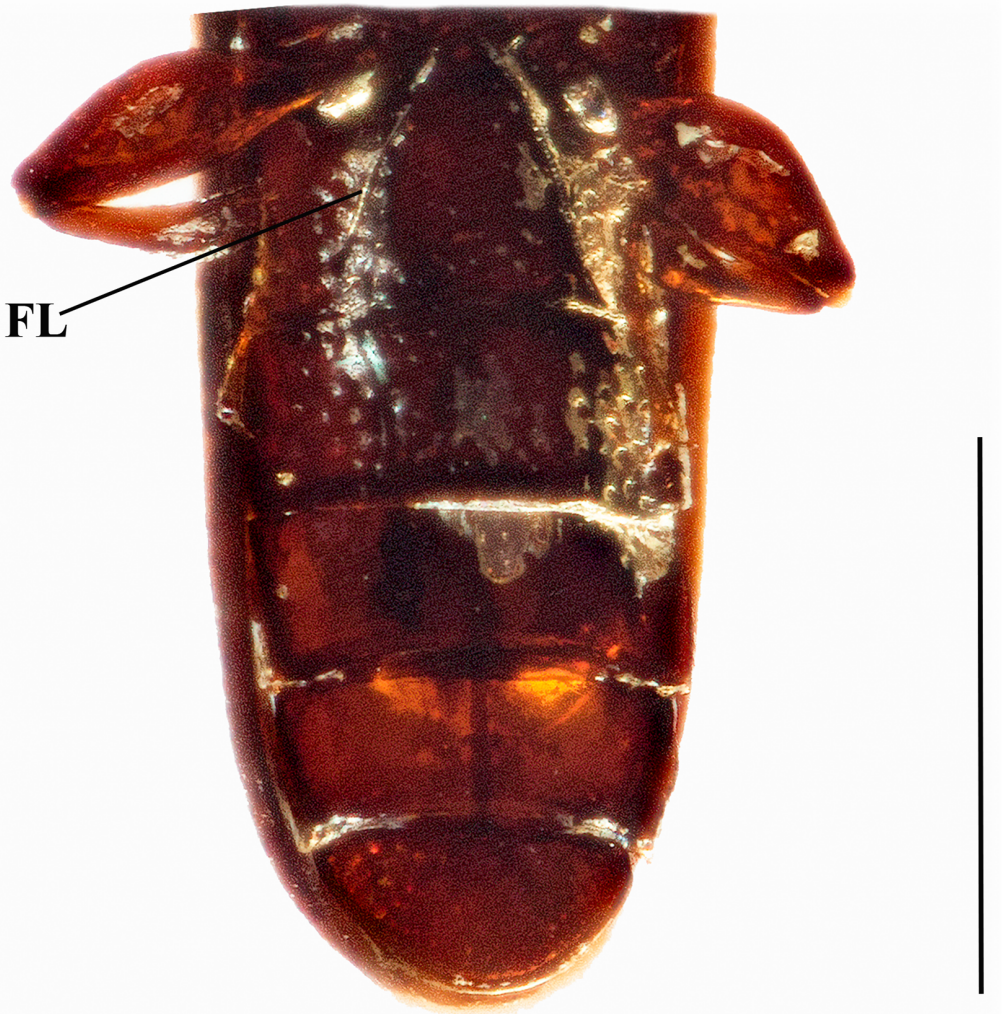

Figure 2. Cathartosilvanus siteiterralevis sp. nov., holotype, P3300.87 (RSM): (a) details of forebody, dorsal view; (b) abdomen, ventral view. Scale bars $=0.5 \mathrm{~mm}$. Abbreviations: D: sharp denticle at posterior pronotal angle; FL: femoral line. 


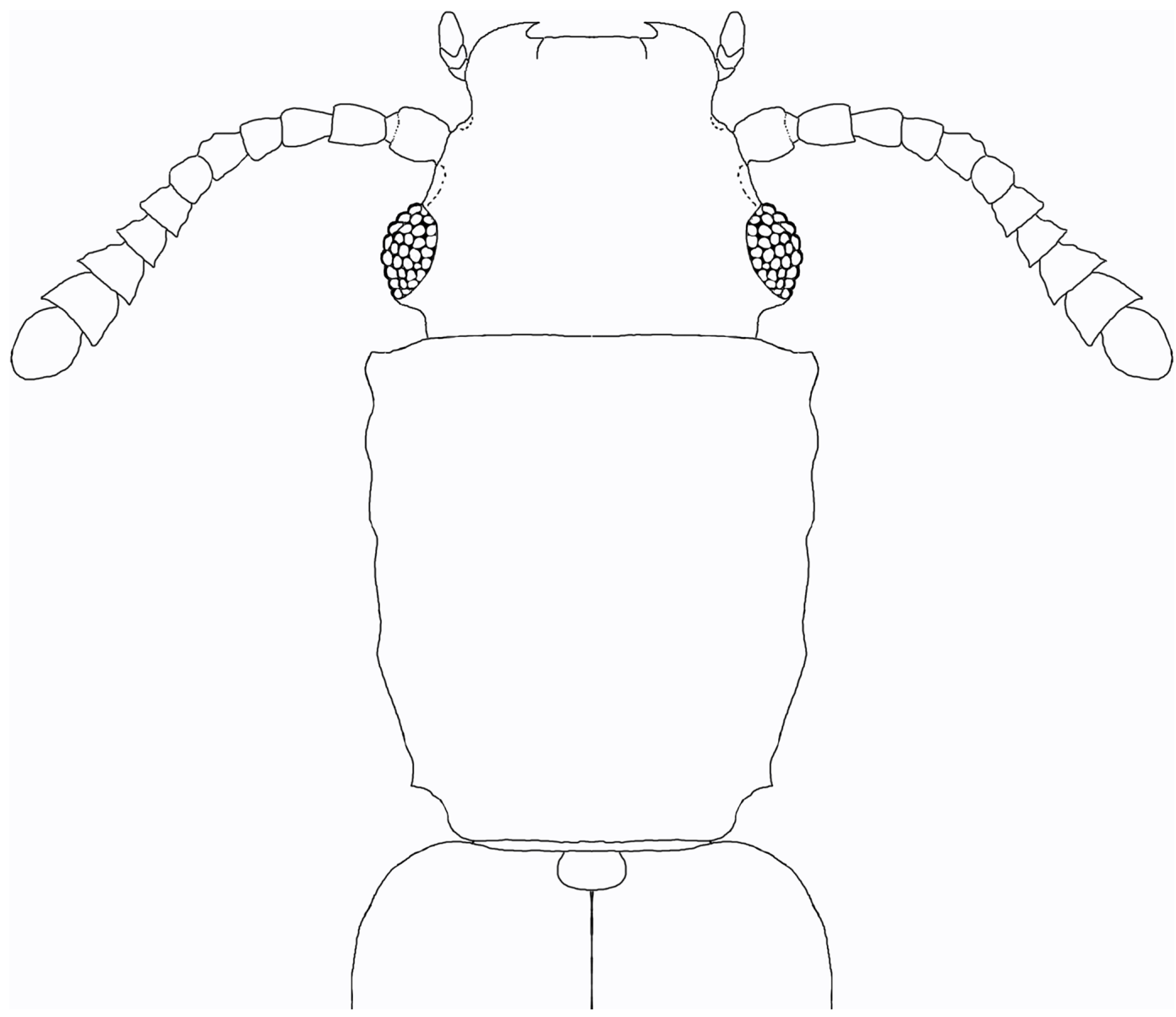

Figure 3. Cathartosilvanus siteiterralevis sp. nov., dorsal outline reconstruction of forebody. Scale bar $=0.5 \mathrm{~mm}$.

tinct club apparently composed of three segments; sparsely covered with fine semi-erect setae; scape subcylindrical, about as long as wide; pedicel subconical, elongate, about $1.8 \times$ as long as wide; antennomere 3 conical, elongate, slightly shorter and narrower than pedicel; antennomeres 4 6 subquadrate; antennomeres 7-8 transverse, subequal in shape and size, and about $1.3 \times$ as wide as long; antennomere 9 strongly transverse, $1.6 \times$ as wide as long, and apparently with fine spines on anterior angles; antennomere 10 largest, transverse, $1.4 \times$ as wide as long, with fine spines on anterior angles; antennomere 11 ovoid. Relative length ratios of antennomeres $1-11$ equal to $11: 14: 11: 9: 9: 9: 8: 8: 8$ : $11: 16$.

Pronotum slightly elongate, $1.2 \times$ as long as wide, widest in anterior one-third of its length, and slightly narrowed posteriad; pronotal punctation fine and sparse, each puncture distinctly smaller than compound eye facet; disc with widely elongate-oval impression that is symmetrical in relation to median line. Anterior and posterior pronotal edges almost straight. Pronotal lateral sides almost parallel-sided in anterior three-quarters and oblique in posterior one-quarter of their lengths; weakly undulated, with small and sharp denti- cle at posterior angle, and with obtuse denticle anterolaterally. Anterior angles nearly rectangular, weakly developed, not produced anteriorly; posterior angles obtuse.

Scutellar shield distinct, suboval, transverse. Elytra elongate, $2.8 \times$ as long as wide, and subparallel-sided, slightly wider than pronotum; without distinct carinae; punctation sparse and small (larger than pronotal punctures), forming indistinct rows, but smoothed at apex; scutellary striole absent. Humeral angles rounded. Lateral margins with microcrenulation. Epipleura well-developed, reaching elytral apex, widest at humeri, with sparse, fine punctures.

Relative length ratios of mesoventrite to metaventrite to abdomen are $2: 3: 9$. Prohypomera covered with fine punctation. Prosternal process elongate, strongly dilated apically, truncate, distinctly narrower than anterior margin of mesoventrite. Procoxal cavities closed. Metaventrite with median line, densely covered with small punctation (distance between punctures equal to $0.5-1.5 \times$ diameter of one puncture), and apparently with secondary micropunctation. Metepisterna long and narrow, with almost straight lateral margins. 
Legs short and robust. Procoxa nearly round, mesocoxa oval, metacoxa oval, not extending laterally to meet elytron. All coxae separated from each other: procoxae separated by distance approximately half of procoxal diameter; mesocoxae separated by distance slightly smaller than mesocoxal diameter; metacoxae widely separated. Trochanters apparently without spines. Femora widened medially, simple (without denticles or teeth), but with deep, longitudinal groove apicoventrally. Tibiae curved, dilated apically, shorter than femora; with minute apical spine. Tarsal formula 5-5-5; tarsomeres 1-3 dilated apically, tarsomere 4 very small; tarsomere 5 longest, about as long as tarsomeres 1-3 combined. Tarsal claws simple, equal in size, long, about $0.3 \times$ as long as apical tarsomere.

Abdomen with five visible, similarly articulated ventrites; ventrite 1 with open femoral line (diverging posteriorly from margin of metacoxal cavities); ventrite 5 rounded apically; ventrites 1-4 sparsely covered with fine punctures, and ventrite 5 with much denser punctation, distance between punctures smaller than diameter of one puncture. Intercoxal process of abdominal ventrite 1 triangular and acute. Relative lengths (medially) of ventrites $1-5$ equal to $31: 22: 20: 17$ : 19.

\section{Discussion}

The preservation state and completeness of the Baltic amber inclusions can differ significantly from one specimen to the next. Damage that results in the distortion and loss of body parts is the most relevant for the current study, and this form of damage can have important implications for descriptions of fossil species based on amber inclusions. This type of damage can occur at different points in the taphonomic history of each specimen, and it has three main causes that could be loosely grouped into the following categories.

1. Pre- or perimortem damages (during or prior to entrapment in natural resin) damages include a loss of appendages during life, or a fall into fresh resin of a dead or damaged specimen. Sometimes, appendage losses can occur during entrapment of a living insect in resin, due to its struggle for release.

2. Postmortem damages (after entrapping, during the polymerization of resin and subsequent transformation of resin to copal) include distortions of external 3-D morphology and changes of body proportions. This type of damage is less typical among Baltic amber inclusions and can usually be found in insects with a soft body cuticle only. The dehydration of the insect body entrapped in resin leads to decrease in the volume of liquid within body and, in the case of a pliable cuticle, to compression of the body. In specimens where the sclerites are loosely bound to one another (e.g., cast exuviae and dried bod- ies), resin flows prior to polymerization may also scatter some of the body parts.

3. Post-extraction damages (breakage, deterioration, and alteration of amber outside of its original anoxic sediments) are usually slow weathering or oxidation processes in natural settings, or extremely rapid anthropogenic changes during extraction, treatment, and processing of amber. Extraction damage of inclusions can be especially evident after mechanical treatments (e.g., loss of body parts during amber cutting and polishing); autoclave processing of samples can have equally deleterious effects - according to Hoffeins (2012), this processing can lead to fragmentation of cuticle, disconnection of body segments, compression and shrinking of body parts, thermal degradation of cuticle, and black discoloration.

The specimen under study represents the comparatively rare (especially among well-sclerotized imago of Coleoptera) postmortem distortion. The specimen is complete but almost disconnected along its head-prothorax and pro-mesothorax articulations. The integument is dorsoventrally compressed and partially translucent but at the same time not black or artificially darkened. We interpret this combination of preservational features as the result of resin trapping the beetle within its imaginal stage, just after the final pupal ecdysis. The exoskeleton was not completely hardened but was somewhat soft and pliable. A single occurrence of such a juvenile imago in amber should be considered a rare occurrence, but future collections of similar material should be examined to see if this form of preservation occurs repeatedly. If it is a repetitive occurrence, the phenomenon might suggest a close ecological association between the resin-producing trees and a particular beetle species, or it may provide evidence of fresh resin attracting this species.

Data availability. No data sets were used in this article.

Author contributions. VIA, AB, and RCM prepared the paper and contributed to the editing.

Competing interests. The authors declare that they have no conflict of interest.

Acknowledgements. The study was carried out with the support of the state assignment of IO RAS (theme no. 0149-2019-0013) to Vitalii I. Alekseev and a Natural Sciences and Engineering Research Council of Canada Discovery Grant (2015-00681) to Ryan C. McKellar. 
Financial support. This research has been supported by the IO RAS (grant no. 0149-2019-0013) and the Natural Sciences and Engineering Research Council of Canada Discovery Grant (grant no. 2015-00681).

Review statement. This paper was edited by Florian Witzmann and reviewed by Andrei Legalov and one anonymous referee.

\section{References}

Alekseev, V. I.: First record of Cathartosilvanus Grouvelle (Coleoptera: Silvanidae) from Baltic amber with description of a new species, Baltic Journal of Coleopterology, 17, 43-48, 2017.

Alekseev, V. I. and Bukejs, A.: New fossil genus of Silvanidae (Insecta: Coleoptera) from Baltic amber (Tertiary, Eocene), Zootaxa, 4144, 101-108, https://doi.org/10.11646/zootaxa.4144.1.5, 2016.

Bachofen-Echt, A.: Der Bernstein und seine Einschlüsse, Springer, Wien, 1949.

Berendt, G.: Die im Bernstein befindlichen organischen Reste der Vorwelt gesammelt in Verbindung mit mehreren bearbeitet. Erster Band. Abtheilung I. Der Bernstein und die in ihm befindlichen Pflanzenreste der Vorwelt, Nikolaische Buchhandlung, Danzig, 1845.

Bukejs, A., Alekseev, V. I., and Pollock, D. A.: Waidelotinae, a new subfamily of Pyrochroidae (Coleoptera: Tenebrionoidea) from Baltic amber of the Sambian peninsula and the interpretation of Sambian amber stratigraphy, age and location, Zootaxa, 4664, 261-273, https://doi.org/10.11646/zootaxa.4664.2.8, 2019.

Dunlop, J. A., Kotthoff, U., Hammel, J. U., Ahrens, J., and Harms, D.: Arachnids in Bitterfeld amber: A unique fauna of fossils from the heart of Europe or simply old friends?, Evolutionary Systematics, 2, 31-44, https://doi.org/10.3897/evolsyst.2.22581, 2018.

Ermisch, K.: Airaphilus denticollis n. sp. (Donacia spec. Helm), Entomologische Blätter, 38, 128-129, 1942.

Friedman, A.-L.-L.: The Silvanidae of Israel (Coleoptera: Cucujoidea), Israel Journal of Entomology, 44, 75-98, https://doi.org/10.5281/zenodo.31646, 2015.

Grouvelle, A.: Notes sur les Silvanini [Col. Cucujidae]. Synonymies et descriptions de genres nouveaux et de nouvelles espéces, Annales de la Société entomologique de France, 81, 313-386, 1912.

Halstead, D. G. H.: A revision of the genus Silvanus Latreille (s.1.) (Coleoptera: Silvanidae), Bulletin of the British Museum of Natural History (Entomology), 29, 39-112, 1973.

Handlirsch, A.: Die fossilen Insekten und die Phylogenie der rezenten Formen. Ein Handbuch für Paläontologen und Zoologen, Wilhelm Engelmann, Leipzig, 1908.

Handlirsch, A.: Paläontologie, in: Handbuch der Entomologie, Volume 3, edited by: Schröder, C. W. M., Gustav Fischer, Jena, Germany, 117-306, 1925.

Helm, O.: Beiträge zur Kenntiss der Insecten des Bernsteins, Schriften der Naturforschenden Gesellschaft in Danzig (Anlage C) N. S., 9, 220-231, 1896 .

Hieke, F. and Pietrzeniuk, E.: Die Bernstein-Käfer des Museums für Naturkunde, Berlin (Insecta, Coleoptera), Mitteilungen aus dem Zoologischen Museum Berlin, 60, 297-326, 1984.
Hoffeins, C.: On Baltic amber inclusions treated in an autoclave, Polskie Pismo Entomologiczne, 81, 165-183, https://doi.org/10.2478/v10200-012-0005-z, 2012.

Hoffeins, C. and Hoffeins, H.-W.: Untersuchungen über die Häufigkeit von Inklusen in Baltischem und Bitterfelder Bernstein (Tertiär, Eozän) aus unselektierten Aufsammlungen unter besonderer Berücksichtigung der Ordnung Diptera, Studia dipterologica, 10, 381-392, 2003.

Hope, F. W.: Observations on succinic insects, T. Roy. Ent. Soc. London, 1, 133-147, 1836.

Kirby, W.: The Insects. Coleoptera, in: Fauna Boreali-Americana, or the Zoology Northern parts of British America: containing descriptions of the objects of Natural history collected on the late Northern Land Expeditions, under command of Captain Sir John Franklin, edited by: Richardson, J., R. N. J. Fletcher, Norwich, 1-325, 1837.

Kirejtshuk, A. G.: The oldest representatives of the subfamilies Meligethinae (Coleoptera: Nitidulidae) and Brontinae (Coleoptera: Silvanidae) from Baltic amber and some evolutionary notes, Polskie Pismo Entomologiczne, 80, 729-745, https://doi.org/10.2478/v10200-011-0055-7, 2011.

Klebs, R.: Über Bernsteineinschlüsse im allgemeinen und die Coleopteren meiner Bernsteinsammlung, Schriften der Physikalisch-ökonomischen Gesellschaft zu Königsberg i. Pr, 51, 217-242, 1910.

Larsson, S. G.: Baltic Amber - a Palaeobiological Study, Volume 1, Scandinavian Science Press Ltd., Klampenborg, Denmark, 1978.

Latreille, P. A.: Histoire naturelle, générale et particuliere, des crustacés et des insectes. Ouvrage faisant suite aux oeuvres de Leclerc de Buffon, et partie du cours complet d'histoire naturelle rédigé par C. S. Sonnini, membre deplusieurs Societes savantes, Tome 13, F. Dufart, Paris, 1802.

Latreille, P. A.: Crustacés, Arachnides et partie des Insectes, in: Le Règne Animal, distribué d'après son organisation, pour servir de base a l'histoire naturelle des animaux et d'introduction à l'anatomie comparée, Nouvelle édition, revue et augmentée, Tome V, edited by: Cuvier, G., Paris, Deterville, xxiv + 556 pp., 1829.

Menge, A.: Lebenszeichen vorweltlicher, im Bernstein eingeschlossener Thiere, Programm der öffentlichen Prüfung der Schüler der Petrischule, A. W. Kafemann, Danzig, 1856.

Spahr, U.: Systematischer Katalog der Berstein- und Kopal-Käfer (Coleoptera), Stuttgarter Beiträge zur Naturkunde, Ser. B, 80, 1107, 1981.

Standke, G.: Bitterfelder Bernstein gleich Baltischer Bernstein? - Eine geologische Raum- Zeit- Betrachtung und genetische Schlußfolgerungen, Exkursionsführer und Veröffentlichungen der Deutschen Gesellschaft für Geowissenschaften, 236, 11-33, 2008.

Szwedo, J. and Sontag, E.: The flies (Diptera) say that amber from the Gulf of Gdańsk, Bitterfeld and Rovno is the same Baltic amber, Polskie Pismo Entomologiczne, 82, 379-388, https://doi.org/10.2478/pjen-2013-0001, 2013.

Thomas, M. C.: The flat bark beetles of Florida (Laemophloeidae, Passandridae, Silvanidae). Arthropods of Florida and neighboring land areas, 15, 1-93, 1993. 
Weitschat, W. and Wichard, W.: Baltic amber, in: Biodiversity of fossils in amber from the major world deposits, edited by: Penney, D., Siri Scientific Press, Manchester, 80-115, 2010.

Wolfe, A. P., McKellar, R. C., Tappert, R., Sodhi, R. N., and Muehlenbachs, K.: Bitterfeld amber is not Baltic amber: three geochemical tests and further constraints on the botanical affinities of succinite, Rev. Palaeobot. Palyno., 225, 21-32, 2016.
Wollaston, T. V.: Insecta Maderensia: being an account of the insects of the Islands of the Madeiran Group, J. van Voorst, London, 1854. 